\title{
e-Module in Producing Briquettes from Melinjo (Gnetum gnemon) Shell with Various Particle Sizes and Binder Concentrations for Vocational School Students
}

\author{
Asep Bayu Dani Nandiyanto*, Enjang Rohman, Mustika Nuramalia Handayani, Silmi Ridwan Putri \\ Universitas Pendidikan Indonesia, Jl. Dr. Setiabudi No. 229 Bandung, Indonesia \\ nandiyanto@upi edu, enjangrohman81@upi.edu,mustika@upi.edu, silmiridwanppp@upi.edu
}

\begin{abstract}
The purpose of the research is to study the effect of the use of videos and e-module to understand the production of briquettes from melinjo (Gnetum gnemon) shell with various particle sizes and binder concentrations for vocational school students. The production of melinjo skin briquettes is conducted using two factors of the completely randomized design (particle size and concentration of tapioca). The study of the briquettes characteristics conducted is compressed density, relaxed density, relaxation ratio, percentage of moisture content, burning rate, specific fuel consumption, percentage of resistance index, and percentage of durability index. The learning process used a quasi-experimental method (One-group pretest-posttest). The learning is performed in two sessions by using video and emodule. Evaluation of student learning outcomes conducted through pretest, after video posttest, and after e-module posttest. Based on the analysis of variation, the concentration of tapioca, and the size of the particle have a significant effect on the briquettes' characteristics. The t-test results of the pretest, after video posttest, and after e-module posttest indicated that the average students' knowledge value increases and varies significantly on each test. This e-module can also be used to improve vocational high school students' knowledge of melinjo skin briquettes.
\end{abstract}

Keywords: Briquette, e-Module, Melinjo Skin, Video.

\author{
Corresponding Author \\ *Departemen Pendidikan Kimia, Universitas \\ Pendidikan Indonesia, Jl. Dr. Setiabudi No. 229 \\ Bandung, Indonesia \\ *nandiyanto@upi.edu
}

\section{Introduction}

The electronic module or e-module is a display of information in a book format that is presented electronically which acts as a learning medium that can make the learning process more interesting, interactive, can be done anywhere and can improve the quality of learning (Kadek, 2017); (Sukaryadi, 2018). E-modules have been broadly used as a platform for learning at different levels of schooling, including vocational schools (Mahara and Yoman, 2016). Various vocational high school materials have been converted into e-modules to improve student learning outcomes.

Septranesti and Lazulva (2019) stated that the use of emodules in chemistry learning in vocational students is practical and effective in increasing student knowledge. Prasetiyowati and Tandyonomanu (2018) reported that the use of e-modules will enhance learning outcomes for vocational school students in three-dimensional animation subjects. Solihudin (2018) stated that web-based e-module learning will enhance the development of vocational students to acquire knowledge of physics. In the meantime, the e-modules for agricultural waste processing materials such as biobriquettes have never been established.

Biobriquettes are briquettes produced from organic materials, agricultural waste, or biomass (Martynis, Sundari, and Sari, 2012). Biobriquette is a coal substitute biofuel that is being developed (Sharman, Priyank, and Sharma, 2015). The quality and performance of briquettes are influenced by several factors such as briquette adhesive (Zhang, Sun, and $\mathrm{Xu}, 2018$ ) and the particle size of the briquette producing (Mitchual, Mensah, and Darkwa, 2013). One of the potential agro-industrial wastes that could be used as biobriquettes is melinjo (Gnetum gnemon).

In Indonesia, many melinjo are processed into various processed products. As an example, in West Java melinjo production reached 335 tons in 2016 (BPS, 2018). At the time of processing melinjo, the melinjo skin will be discarded and become waste. On the other hand, vocational high school students majoring in agriculture must have expertise in agro-industrial waste treatment. Therefore, it is necessary to have an e-module in producing melinjo skin briquettes with variations in particle size and binder concentrations for vocational school students. The purpose of the research is to study the effect of the use of videos and 
e-module to understand production of briquettes from melinjo (Gnetum gnemon) shell with various particle sizes and binder concentrations for vocational school students.

\section{Method}

\subsection{Producing Briquettes from Melinjo Skin}

The raw materials for briquette production are waste from melinjo (Gnetum gnemon) skin, tapioca flour, and water. The tools used are a knife, scale, oven, thermometer, and saw-mill. The production of melinjo skin briquettes is conducted using two factors of the complete randomized method with three replication analysis. The first factor is the tapioca concentration at the levels of $10,20,30,40.50 \%$. The second factor is the particle size at levels $1000-465,250$ 125 , and 105-74 $\mu \mathrm{m}$.

The briquettes processing consists of several stages, namely the size reduction, drying $\left(\mathrm{T}=60^{\circ} \mathrm{C}, \mathrm{t}=3 \mathrm{~h}\right)$, carbonization $\left(\mathrm{T}=250^{\circ} \mathrm{C}, \mathrm{t}=2 \mathrm{~h}\right)$, crushing, sieving (according to particle size variable), mixing the raw materials (based on the tapioca concentration variable), molding with a pressure $14 \mathrm{~N} / \mathrm{cm}^{2}$, and drying the briquettes until the weight is constant $\left(\mathrm{T}=130^{\circ} \mathrm{C}\right)$.

The analysis on the melinjo skin bio briquette characteristics includes the compressed density (CD), relaxed density (RD), relaxed ratio (RR), percentage moisture content (PMC), burning rate (BR), specific fuel consumption (SFC), percentage of resistance index (PWRI), and percentage of durability index (PDI). The data were processed using a $5 \%$ analysis of variance to determine the significance of the variables on the characteristics.

\subsection{Teaching Method}

Research participants are 28 students of grade 11 vocational high schools in Bandung, Indonesia. Students' demographic data are collected including the IQ level, report scores on Mathematics, Biology, agricultural machine tools, and basic cultivation to identify students' preliminary condition.

The learning process uses a quasi-experimental method one-group pretest-posttest. The learning is conducted in two sessions; each session is carried out in one learning meeting. The first session is learning using video. The video explains the manufacturing process and characteristics of the melinjo skin briquettes which are uploaded on Google Drive in the mp4 format. The evaluation of the first session of learning uses a pretest to determine students' initial knowledge of melinjo skin briquettes and a posttest to determine the effect of using video on student knowledge.

The second learning session uses the melinjo skin briquette e-module. The e-module is made based on the results of the posttest after video to improve students' understanding of melinjo leather briquettes. The e-module creation uses the flipbook maker platform. The e-module is shown in Figure 1. The second session of learning evaluation is carried out using posttest after e-module. Evaluation is conducted to determine the level of students' knowledge after learning using e-modules. The pretest and posttest questions consisted of 10 true and false questions about melinjo skin briquettes.

Furthermore, the first and second session data of the pretest, posttest after video, and posttest after e-module are processed using the paired t-test to determine the increase in student understanding after learning using video and emodule.

\section{Results and Discussion}

\subsection{Melinjo skin briquette characteristics}

\subsubsection{Compressed density (CD)}

The effect of tapioca concentration and particle size on compressed density is illustrated in Figure 2. The results of the analysis of variance show that the treatment of tapioca concentration and particle size has a significant effect ( $\rho$ $<0.05$ ) on the compressed density and the treatment interaction have a significant effect $(\rho<0.05)$ on the compressed density.

Figure 2 displays a briquette with a 50\% tapioca concentration with a particle size of 105-74 $\mu \mathrm{m}$ having the highest compressed density value with an average value of $1.19 \mathrm{~g} . \mathrm{cm}^{-3}$. The lowest compressed density is on melinjo skin briquettes with a $10 \%$ tapioca concentration with a particle size of $1000-465 \mu \mathrm{m}$ and with an average value of $0.97 \mathrm{~g} . \mathrm{cm}^{-3}$. The smaller the particle size and the higher the tapioca concentration, the higher the $\mathrm{CD}$ briquette value. This is consistent with Davies's research (2014), which notes that the $\mathrm{CD}$ value is directly proportional to the concentration of the binder due to the interaction of the adhesive with carbon particles increases with higher tapioca concentrations and finer particle size (Olorunnisola, 2007).

\subsubsection{Relaxed Density (RD)}

The effect of tapioca concentration and particle size on relaxed density $(\mathrm{RD})$ is shown in Figure 3. The results of the analysis of variance show that the treatment of tapioca concentration and particle size has a significant effect ( $\rho$ $<0.05$ ) on RD and the treatment interaction has a significant effect $(\rho<0.05)$ on RD.

Figure 3 illustrates that briquettes with $50 \%$ tapioca concentration at a particle size of $105-74 \mu \mathrm{m}$ have the highest RD average, namely $90 \mathrm{~g} . \mathrm{cm}^{-3}$. The lowest RD is melinjo skin briquettes with $10 \%$ of tapioca concentration at a particle size of 1000-465 $\mu \mathrm{m}$ with an average value of 0,49 g. $\mathrm{cm}^{-3}$.

The larger the particle size and the smaller the tapioca concentration, the lower the RD value of briquettes. Mitchual, Mensah, and Darkwa (2013) found that briquettes with small particle sizes tend to have a higher RD value than those with a larger particle size as it is related to the interaction of a wider surface area of the material with the adhesive, thus giving a higher $\mathrm{RD}$ value. 


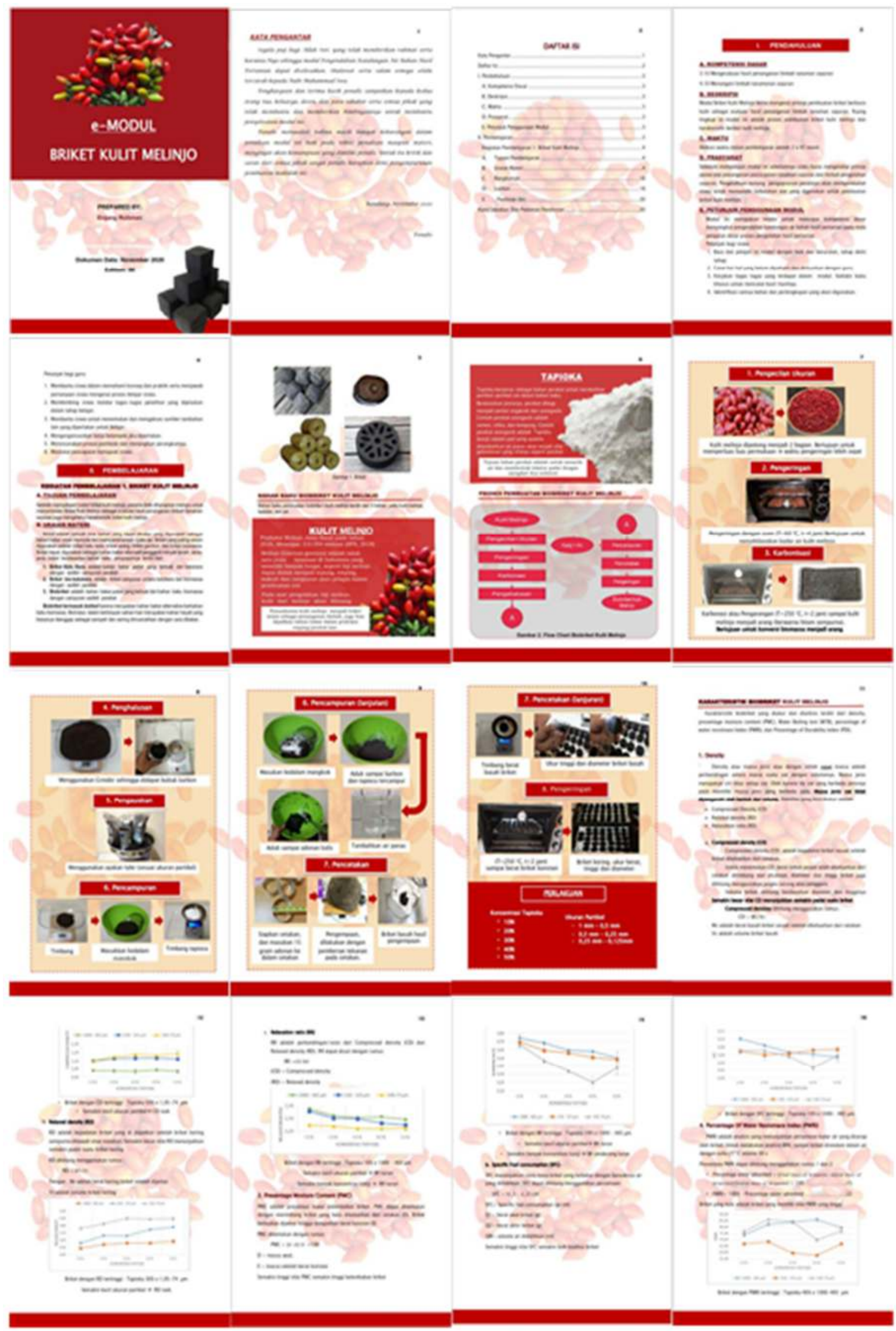

Fig 1. The e-module appearance 


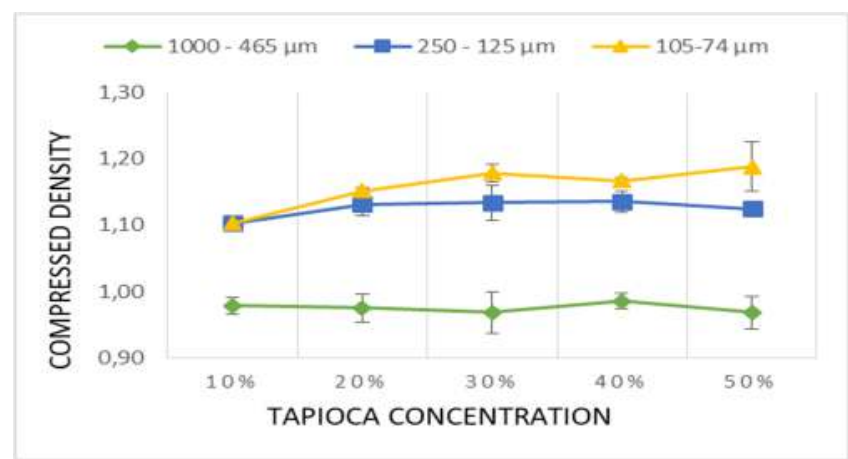

Fig. 2 Effect of tapioca concentration and particle size on CD

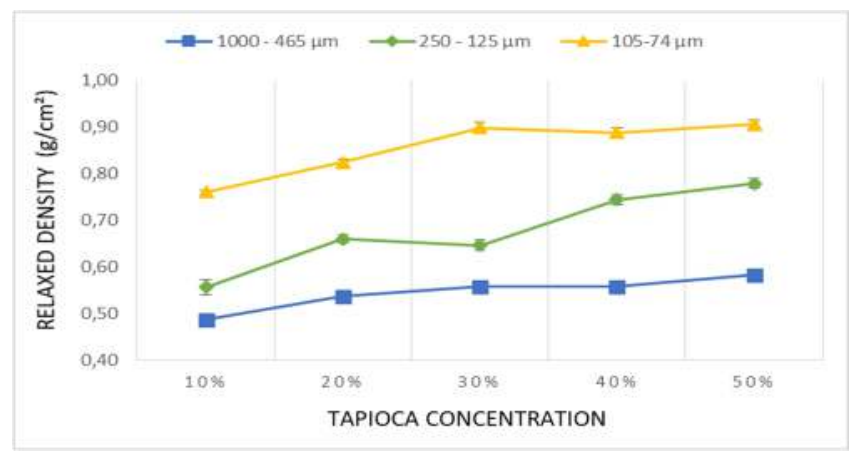

Fig. 3 Effect of tapioca concentration and particle size on RD

\subsubsection{Relaxed Ratio (RR)}

The effect of tapioca concentration and particle size on the relaxed ratio (RR) can be seen in figure 4 . The results of the analysis of variance show that the treatment of tapioca concentration and particle size has a significant effect ( $\rho$ $<0.05)$ on RR and the treatment interactions has a significant effect $(\rho<0.05)$ on RR.

Based on Figure 4, the briquette with the highest RR is $10 \%$ tapioca concentration briquettes with a particle size of $1000-465 \mu \mathrm{m}$ and with an average value of 2.08 . The lowest $\mathrm{RR}$ is briquette with $30 \%$ tapioca concentration with a particle size of 105-74 $\mu \mathrm{m}$ with an average value of 1,31 g. $\mathrm{cm}^{-3}$. The larger the particle size and the lower the tapioca concentration, the higher the RR briquettes value. This is in line with research (Olorunnisola, 2007) which states that briquettes with high $\mathrm{CD}$ and $\mathrm{RD}$ provide relatively lower RR values.

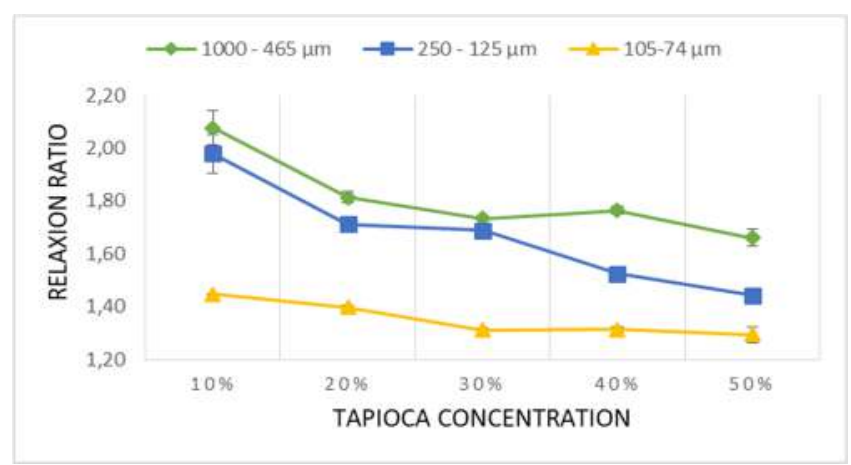

Fig. 4 Effect of tapioca concentration and particle size on the RR

\subsubsection{Percentage moisture content (PMC)}

The effect of tapioca concentration and particle size on PMC briquettes is displayed in Figure 5. The results of the analysis of variance show that the treatment of tapioca concentration and particle size has a significant effect ( $\rho$ $<0.05$ ) on PMC and the treatment interaction has a significant effect $(\rho<0.05)$ on PMC briquettes. Onukak, Dabo, and Ameh (2017) stated that briquettes with finer particles will have higher humidity.

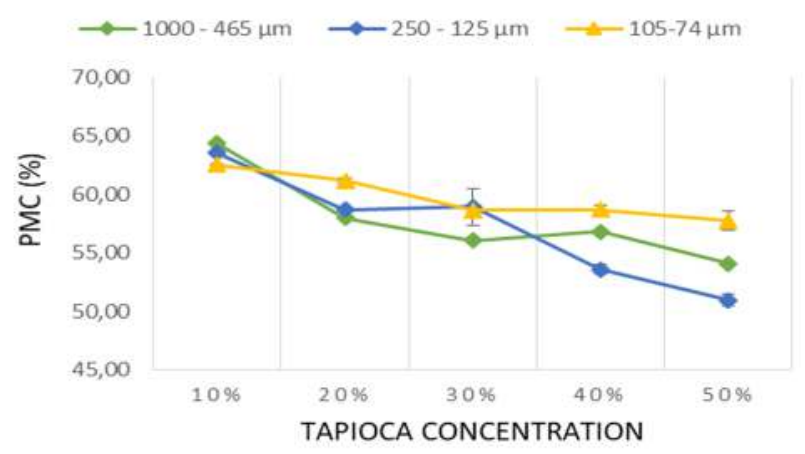

Fig. 5 Effect of tapioca concentration and particle size on PMC

\subsubsection{Burning Rate (BR)}

The BR value shows the average period of briquette burned per unit of time (Onukak, Dabo, and Ameh, 2017). Figure 6 shows the effect of tapioca concentration and particle size on the BR value. The results of the analysis of variance show that the treatment of tapioca concentration and particle size has a significant effect $(\rho<0.05)$ on the BR value and the treatment interaction has a significant effect ( $\rho$ $<0.05$ ) on the BR briquettes.

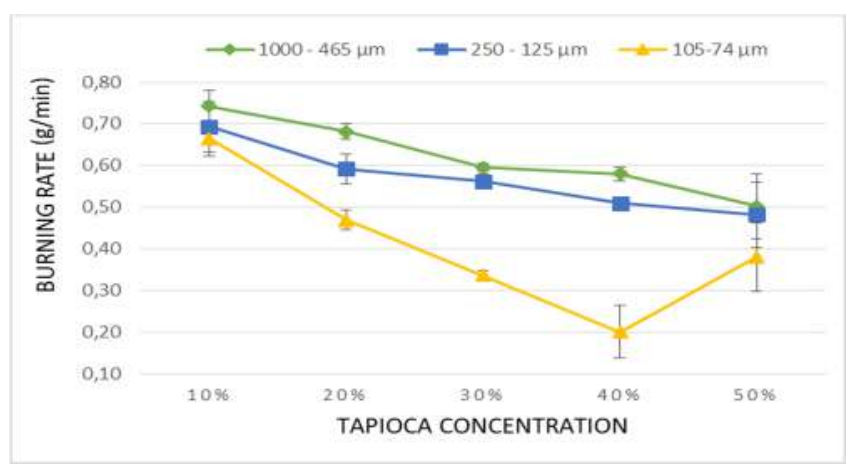

Fig. 6 Effect of tapioca concentration and particle size on BR

Figure 6 displays that the briquette with the highest BR is the $10 \%$ of tapioca concentration with a particle size of $1000-465 \mu \mathrm{m}$ and with an average value of $0.74 \mathrm{~g} /$ minute. The lowest BR is the briquette with $40 \%$ tapioca concentration with a particle size of 105-74 $\mu \mathrm{m}$ with an average value of $0.2 \mathrm{~g} /$ minute. The larger the particle size 
and the lower the tapioca concentration, the higher the BR value of the briquettes. Meanwhile, Onukak, Dabo, and Ameh, (2017) stated that briquettes with less adhesive will burn faster than those with much adhesive and the particle size of briquettes is inversely proportional to the burning rate of the briquettes.

\subsubsection{Specific Fuel consumption (SFC)}

SFC is the amount of fuel (briquettes) needed to boil water per unit of a minute (Rajaseenivasan, Srinivasan, Qadir, and Srithar, 2016). Figure 7 shows the effect of tapioca concentration and particle size on SFC briquettes. The results of the analysis of variance show that the treatment of tapioca concentration and particle size has a significant effect $(\rho<0.05)$ on and the treatment interaction has a significant effect $(\rho<0.05)$ on the SFC of briquettes.

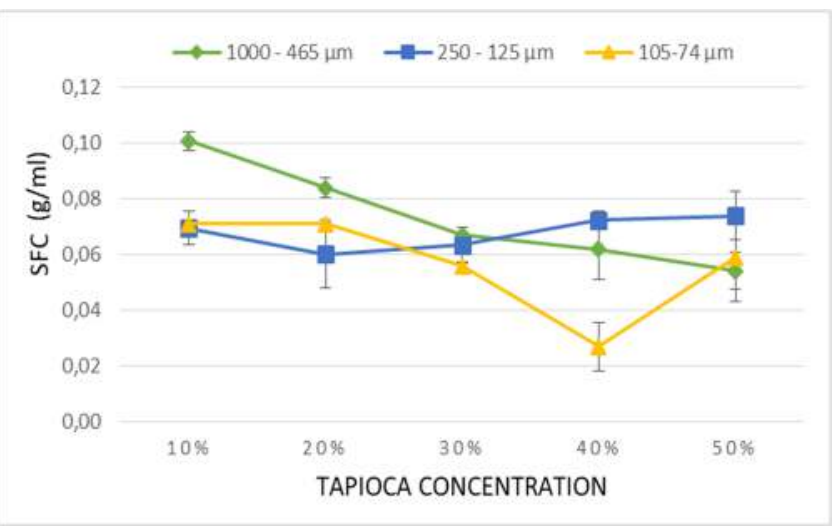

Fig. 7 Effect of tapioca concentration and particle size on SFC

Based on Figure 7, the briquette with the highest SFC is the $10 \%$ of tapioca concentration briquettes with a particle size of $1000-465 \mu \mathrm{m}$ and with an average value of $0,1 \mathrm{~g} / \mathrm{ml}$. The lowest SFC is briquette with $40 \%$ of tapioca concentration with a particle size of $105-74 \mu \mathrm{m}$ and with an average value of $0,03 \mathrm{~g} / \mathrm{ml}$. The larger the particle size and the lower the tapioca concentration, it tends to increase the SFC value of the briquettes. Although at the size of 250-125 $\mu \mathrm{m}$, the higher the tapioca concentration, the higher the SFC value. According to Rajaseenivasan, Srinivasan, Qadir, and Srithar (2016), the SFC value is highly dependent on the calorific value of the ingredients and the addition of adhesive can reduce the calorific value of a briquette.

\subsubsection{Percentage of Resistance Index (PWRI)}

The percentage of resistance index (PWRI) is performed to determine the level of resistance of briquettes to water exposure (Kpalo, Zainuddin, and Manaf, 2020). Figure 8 shows the effect of tapioca concentration and particle size on PWRI briquettes. The results of the analysis of variance show that the treatment of tapioca concentration and particle size has a significant effect $(\rho<0.05)$ on the PWRI value and the treatment interaction has a significant effect $(\rho<0.05)$ on the PWRI of briquettes. Kpalo, Zainuddin, and Manaf(2020) stated that the value of water resistance is related to briquette density, low density can reduce briquette water resistance (Kpalo, Zainuddin, and Manaf, 2020).

\subsection{Percentage of Durability Index (PDI)}

The percentage of the durability index is the capacity of briquettes to remain intact and the resistance of briquettes not to break due to collisions or during storage and transport (Olugbade, Ojo, and Mohammed, 2019). Figure 9 shows the effect of tapioca concentration and particle size on the PDI value of briquettes. The results of the analysis of variance show that the treatment of tapioca concentration and particle size has a significant effect ( $\rho$ $<0.05$ ) on the PDI value and the treatment interaction has a significant effect $(\rho<0.05)$ on the PDI value of briquettes.

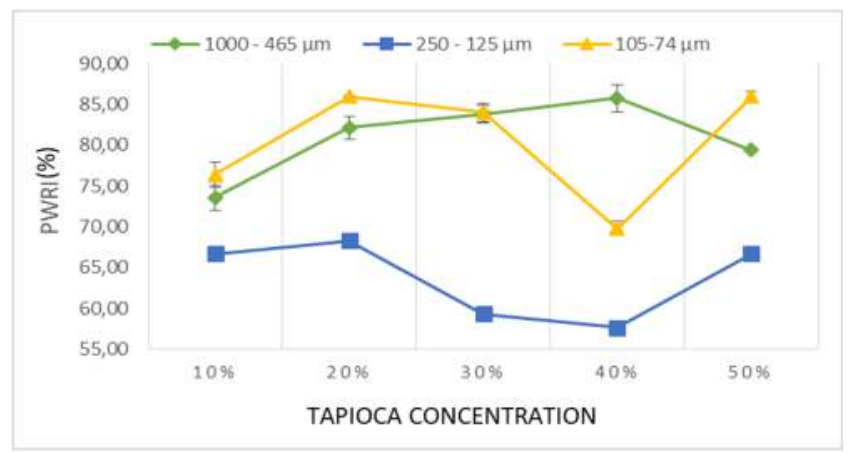

Fig. 8 Effect of tapioca concentration and particle size on PWRI briquettes

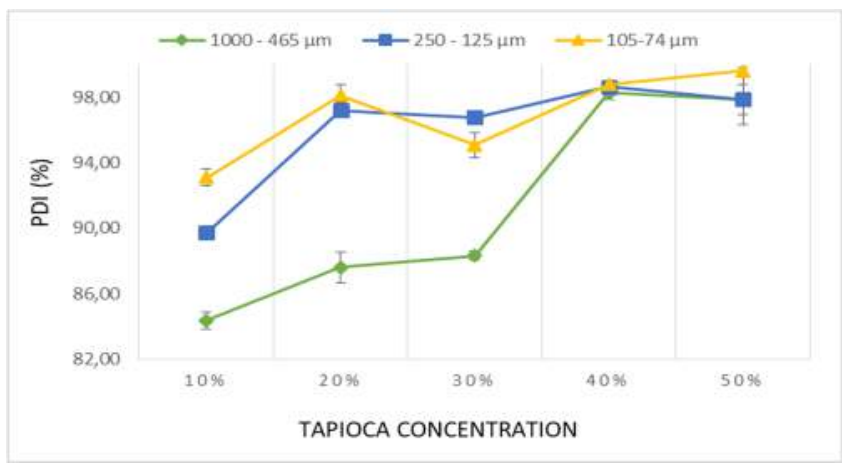

Fig. 9 Effect of tapioca concentration and particle size on PDI briquettes

Figure 9 shows the PDI value at particle size 1000-465 $\mu \mathrm{m}$ and is smaller than the particle size $250-125$, and 105$74 \mu \mathrm{m}$. Martynis, Sundari, and Sari (2012) explained that the finer the particle size, the stronger the bio briquette produced. Besides, the size of the two particles indicated that the higher the tapioca content, the higher the PDI value. The high concentration of tapioca increases the bond between the particles and the binder and improving the durability of the briquettes (Olugbade, Ojo, and Mohammed, 2019).

\subsection{Teaching Results}




\subsubsection{Student demographics Data}

Based on the IQ score, respondents were divided into low IQ (80-89 IQ), medium (90-109 IQ), and high (110-119) IQ (Suryani, Labellapansa, Shiddiqie, and Hidayat, 2019). Figure 10 shows the student's IQ score. There are 46\% (13 students) who have low IQ, 39\% (11 students) are at a moderate IQ level, and 14\% of students (4 students) have a high IQ.

Students' scores on several subjects may indicate students' interest in the topic being studied shown in Table 1. The table also shows the students' abilities that can support students in understanding melinjo skin briquettes.

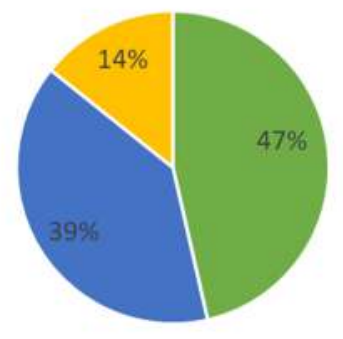

= low $\mathbf{m}$ medium $=$ high

Fig. 10 Groups of Student IQ

Table 1. Students average scores based on students' school report

\begin{tabular}{|l|l|l|}
\hline \multicolumn{1}{|c|}{ No } & \multicolumn{1}{|c|}{ Subject } & \multicolumn{1}{|c|}{ Average score } \\
\hline 1. & Mathematics & 81.58 \\
\hline 2. & Biology & 77.39 \\
\hline 3. & Agricultural Machine Tools & 81.00 \\
\hline 4. & Basic Cultivation & 77.65 \\
\hline
\end{tabular}

\subsubsection{Learning Outcomes Analysis}

Students learning outcomes in two sessions evaluated using the pretest and posttest shown in Table 2. The students' pretest and posttest questions are the ten true-false statements that are used to assess students' understanding of the melinjo skin briquette material. The pretest results show students' initial knowledge about melinjo skin briquettes. Students' initial knowledge about skin briquettes melinjo including the less, it can be seen from the average pretest score of 43.79

Table 2 shows students' learning outcomes have improved in each session. There is an increase in the value of each question indicator after the use of the video and emodule. After the first learning session (using video), students' knowledge increases with an average score of 68.27. Likewise, in learning using e-module, the average student's knowledge increases up to 80 . Thus, the use of videos and e-modules can improve students' knowledge. This is in line with literature that additional media can improve the learning process for students (Maryanti, Hufad, Sunardi, Nandiyanto, and Al-Obaidi, 2020; Nandiyanto, Asyahidda, Danuwijaya, Abdullah, Amelia, Hudha, and Aziz, 2018; Nandiyanto, Raziqi, Dallyono, and Sumardi, 2020).
Table 2. Students learning outcomes

\begin{tabular}{|c|c|c|c|c|}
\hline \multirow[b]{2}{*}{ No } & \multirow[b]{2}{*}{ Question } & \multirow[b]{2}{*}{ Pretest } & \multicolumn{2}{|c|}{ Posttest } \\
\hline & & & $\begin{array}{l}\text { After } \\
\text { video }\end{array}$ & $\begin{array}{c}\text { After } \\
\text { e- module }\end{array}$ \\
\hline 1. & $\begin{array}{l}\text { Briquettes' raw materials } \\
\text { are divided into coal } \\
\text { briquettes, bio-coal } \\
\text { briquettes, and bio bricks. }\end{array}$ & 58.62 & 89.66 & 100.00 \\
\hline 2. & $\begin{array}{l}\text { Coal briquettes serve as } \\
\text { biofuel as they can be used } \\
\text { continually as fuel. }\end{array}$ & 3.45 & 27.59 & 75.86 \\
\hline 3. & $\begin{array}{l}\text { Briquettes are made by } \\
\text { combining carbonized raw } \\
\text { materials with adhesive } \\
\text { ingredients. Carbonization } \\
\text { is the process of } \\
\text { transforming organic } \\
\text { material into charcoal. }\end{array}$ & 51.72 & 82.76 & 86.21 \\
\hline 4. & $\begin{array}{l}\text { The purpose of the } \\
\text { adhesive on the briquette is } \\
\text { to attract water and form a } \\
\text { solid texture by binding } \\
\text { the two substrates. }\end{array}$ & 44.83 & 75.86 & 82.76 \\
\hline 5. & $\begin{array}{l}\text { The smaller the size of the } \\
\text { carbonized raw materials, } \\
\text { the higher the density of } \\
\text { the briquettes so the } \\
\text { briquettes are stronger. }\end{array}$ & 62.07 & 75.86 & 79.31 \\
\hline 6. & $\begin{array}{l}\text { Density is the ratio } \\
\text { between the briquette mass } \\
\text { and volume. The density } \\
\text { of the briquette is affected } \\
\text { by its shape and volume. }\end{array}$ & 34.48 & 44.83 & 75.86 \\
\hline 7. & $\begin{array}{l}\text { BR is the average burnt } \\
\text { time of the briquette. The } \\
\text { better the briquette, the } \\
\text { lower the burning rate. }\end{array}$ & 37.93 & 65.52 & 72.41 \\
\hline 8. & $\begin{array}{l}\text { BR is the average burnt } \\
\text { time of the briquette. The } \\
\text { smaller the particle size, } \\
\text { the lower the BR value. }\end{array}$ & 55.17 & 79.31 & 96.55 \\
\hline 9. & $\begin{array}{l}\text { PWRI is an analysis that } \\
\text { shows the percentage of } \\
\text { water absorbed by the } \\
\text { briquette. Good briquettes } \\
\text { are briquettes that have a } \\
\text { high PWRI value. }\end{array}$ & 44.83 & 65.52 & 86.21 \\
\hline 10 & $\begin{array}{l}\text { The higher the SFC, the } \\
\text { better the briquette quality } \\
\text { (more economical). }\end{array}$ & 44.83 & 75.86 & 86.21 \\
\hline
\end{tabular}

The level of significance of students' knowledge before and after the use of video is shown in Table 3. The results of the paired t-test using video in the first session have a significant effect $(\rho<0.05)$ on student learning outcomes with a value of $\rho=0.005$. This is in line with literature that adding video significantly increased participant's cognitive load when learning procedural knowledge (Hong, Pi and Yang, 2018).

The value of student knowledge after learning using emodule is higher than using video. The level of significance of students' knowledge after the use of video and e-module is shown in Table 4. The application of e-module has a significant effect $(\rho<0.05)$ on student learning outcomes after the use of videos with a value of $\rho=0.02$. This is because e-modules are made based on the results of 
evaluating student knowledge after the use of videos so that they can correct misunderstandings and increase student knowledge scores. Using e-modules as a learning tool makes the learning process more interesting, interactive, accessible, and can enhance the quality of learning (Sukaryadi, 2018). According to Mulyadi, Atmazaki, and Syahrul, (2019), one of the advantages of using e-modules is that it can inspire students as the assignments are limited by students' abilities, therefore, the use of e-modules can improve the quality of students' comprehension.

Table 3. Paired sample test pretest and after video

\begin{tabular}{lrr}
\hline & pretest & \multicolumn{1}{c}{$\begin{array}{c}\text { After } \\
\text { video }\end{array}$} \\
\hline Mean & 43.79310345 & 68.62069 \\
Variance & 277.579601 & 352.6225 \\
Observations & 10 & 10 \\
Pooled Variance & 315.1010702 & \\
Hypothesized Mean & 0 & \\
Difference & 18 & \\
df & & \\
t Stat & & \\
P(T<=t) one-tail & 0.002909283 & \\
t Critical one-tail & 1.734063607 & \\
P(T<=t) two-tail & 0.005818566 & \\
t Critical two-tail & 2.10092204 & \\
\hline
\end{tabular}

\begin{tabular}{lrr}
\multicolumn{3}{c}{ Table 4. Paired sample test after video and after e-module } \\
\hline & $\begin{array}{c}\text { After } \\
\text { video }\end{array}$ & $\begin{array}{l}\text { After } e^{-} \\
\text {module }\end{array}$ \\
\hline Mean & 68.27586 & 84.13793 \\
Variance & 353.5474 & 79.79918 \\
Observations & 10 & 10 \\
Pooled Variance & 216.6733 & \\
Hypothesized Mean & & \\
Difference & 18 & \\
df & & \\
t Stat & -2.40958 & \\
P $(T<=t)$ one-tail & 0.013446 & \\
t Critical one-tail & 1.734064 & \\
P(T<=t) two-tail & 0.026892 & \\
t Critical two-tail & 2.100922 & \\
\hline
\end{tabular}

\section{Conclusion}

Based on the analysis of variance, the tapioca concentration, and the size of the particle affect the briquettes characteristics significantly. Briquettes with relaxation ratio value, percentage moisture content, burning rate, and the highest specific fuel consumption are on briquettes with the $10 \%$ tapioca concentration and particle size of 1000-465 $\mu \mathrm{m}$. Meanwhile, briquettes with compressed density, relaxed density value, percentage of durability index, and the highest percentage of water resistance index are on briquettes with $50 \%$ of tapioca concentration and the particle size of 105-74 $\mu \mathrm{m}$. Based on the t-test results of the pretest, after video posttest, and after e-module posttest, show that the average students' scores have improved and are significantly different on each test. The use of e-modules as a learning medium makes the learning process more interesting, interactive, and increases student motivation to study independently. Thus, the emodule can also be used to improve vocational students' understanding of melinjo skin briquettes.

\section{Acknowledgement}

We would like to thank the agro-industrial technology education study program and faculty of technology and vocational education for the supports have given. We also thank teachers and students of SMK PPN Lembang for their assistance during this experiment. We acknowledged RISTEK BRIN for grant in aid Penelitian Terapan Unggulan Perguruan Tinggi and Bangdos Universitas Pendidikan Indonesia.

\section{References}

Badan Pusat statistik. (2018). Produksi tanaman sayuran (cabe rawit, blewah, jamur, melinjo, petai dan kacang merah) menurut kabupaten/kota di provinsi jawa barat, 2016. Retrieved $28^{\text {th }}$ November, 2020 from bps: https://jabar.bps.go.id/statictable/2018/03/14/322/Produksitanaman-sayuran-cabe-rawit-blewah-jamur-melinjo-petaidan-kacang-merah-menurut-kabupaten-kota-di-provinsijawa-barat-2016.html

Davies, R. M. (2014). Physical characteristics of some biomassa briquettes. journal of advanced and applied sciences, 2(2), 72-81.

Hong, J., Pi, Z. Yang, J. (2018). Learning declarative and procedural knowledge via video lectures: cognitive load and learning effectiveness. Innovations in Education and Teaching International. 55(1), 74-81.

Kadek, A. P. (2017). Pengembangan E-Modul Berbantuan Simulasi Berorientasi pemecahan masalah pada mata pelajaran komunikasi data (Studi Kasus Peserta Didik Kelas XI TKJ SMK N 3 Singaraja. Jurnal Karmapati, 6(1), 15-23.

Kpalo, S. Y., Zainuddin, M. F., Manaf, L. A., and Roslan, A. M. (2020). Production and Characterization of Hybrid Briquettes from Corncobs and Oil Palm Trunk Bark under a Low Pressure Densification Technique. Sustainability 12(4), $1-16$.

Mahara, I., and Yoman Sumana Degeng, D. K. (2016). EModul Pembelajaran Bahasa Inggris Untuk Siswa Smp N 1 Takengon. Jurnal Inovasi Dan Teknologi Pembelajaran 1(4), 307-312. 
Martynis, M., Sundari, E., and Sari, E. (2012). Pembuatan Biobriket Dari Limbah Cangkang Kakao. Jurnal Litbang Industri, 1(2), 35-41.

Maryanti, R., Hufad, A., Sunardi, S., Nandiyanto, A. B. D., and Al-Obaidi, A.S.M. (2020). Understanding covid-19 particle contagion through aerosol droplets for students with special needs. Journal of Engineering Science and Technology, 15(3), 1909-1920.

Mitchual, S. J., Frimpong-Mensah, K., and Darkwa, N. A. (2013). Effect of species, particle size and compacting pressure on relaxed density and compressive strength of fuel briquettes. international journal of energy and environmental engineering 4(30), 1-6.

Mulyadi, M., Atmazaki, A., Figure Syahrul, R. (2019). The Development of Interactive Multimedia E-Module on Indonesia Language Course. In 1st International Conference on Innovation in Education (ICoIE 2018). Atlantis Press 178, 291-295.

Nandiyanto, A. B. D., Asyahidda, F. N., Danuwijaya, A. A., Abdullah, A. G., Amelia, N., Hudha, M. N., and Aziz, M. (2018). Teaching "nanotechnology" for elementary students with deaf and hard of hearing. Journal of Engineering Science and Technology, 13(5), 1352-1363.

Nandiyanto, A. B. D., Raziqi, G. Y., Dallyono, R., and Sumardi, K. (2020). Experimental Demonstration for Enhancing Vocational Students' Comprehension on Heat Transfer through Conduction and Radiation of Light Bulb. Journal of Technical Education and Training, 12(3), 189195.

Olorunnisola, A. (2007). production of fuel briquettes from waste paper and coconut husk admixtures. Agricultural engineering international CIGR ejournal 9 (3), 1-11.

Olugbade, T., Ojo, O., and Mohammed, T. (2019). Influence of binders on combustion properties of biomass briquettes: a recent review. BioEnergy Research, 12(2), 241-259.

Onukak, I. E., Mohammed-Dabo, I. A., Ameh, A. O., Okoduwa, S. I., and Fasanya, O. O. (2017). Production and characterization of biomass briquettes from tannery solid waste. Recycling, 2(4), 17.

Prasetiyowati, Y. (2015). Pengembangan Modul Elektronik pada Mata Pelajaran Animasi 3 Dimensi Materi Pokok Pemodelan Objek 3D Kelas XI Multimedia untuk Meningkatkan Hasil Belajar di Smk Negeri 1 Magetan. Jurnal Mahasiswa Teknologi Pendidikan, 6(2). 12-18

Rajaseenivasan, T., Srinivasan, V., Qadir, G. S. M., and Srithar, K. (2016). An investigation on the performance of sawdust briquette blending with neem powder. Alexandria Engineering Journal, 55(3), 2833-2838.

Septryanesti, N., and Lazulva. (2019). Desain Dan Uji Coba E-Modul Pembelajaran Kimia Berbasis Bog Pada Materi Hidrokarbon. Jurnal Tadris Kimiya 4 (2), 202-215.
Sharma, M. K., Priyank, G., and Sharma, N. (2015). Biomass Briquette Production: A Propagation of Non-Convention Technology and Future of Pollution Free Thermal Energy Sources. American Journal of Engineering Research (AJER) 4(2), 44-50.

Solihudin, T. (2018). Pengembangan E-Modul Berbasis Web Untuk Meningkatkan Pencapaian Kompetensi Pengetahuan Fisika Pada Materi Listrik Statis dan Dinamis . Jurnal Wahana Pendidikan Fisika 3(2), 51-56.

Sukaryadi. (2018). Pemanfaatan E-Modul Sebagai Alternatif Media pemeblajaran mandiri. Retrieved $28^{\text {th }}$ November, 2020 from smkn1karanggede: https://www.sman1 karanggede.sch.id/2018/01/23/pemanfaa tan-e-modulsebagai-alternatif-media-pembelajaranmandiri/

Suryani, D., Labellapansa, A., Shiddiqie, M. L., and Hidayat, A. (2019). Kajian Klasifikasi Data Mining IQ Siswa SMA Berdasarkan Hasil Intelligence Structure Test Dengan Menggunakan Metode Naive Bayes. In Seminar Nasional Informatika Medis (SNIMed), 66-72

Zhang, G., Sun, Y., and Xu, Y. (2018). Review of briquette binders and briquetting mechanism. Renewable and Sustainable Energy Reviews, 82, 477-487. 